\title{
Article \\ Description of Intra-Annual Changes in Cambial Activity and Differentiation of Secondary Conductive Tissues of Aesculus hippocastanum Trees Affected by the Leaf Miner Cameraria ohridella
}

\author{
Elżbieta Myśkow ${ }^{1, * \mathbb{D}}$, Katarzyna Sokołowska ${ }^{1}$, Aleksandra Słupianek ${ }^{1}$ (D) and Vladimir Gryc ${ }^{2}$ (D) \\ 1 Department of Plant Developmental Biology, Faculty of Biological Sciences, University of Wrocław, \\ Kanonia 6/8, 50-328 Wrocław, Poland; katarzyna.sokolowska@uwr.edu.pl (K.S.); \\ aleksandra.slupianek@uwr.edu.pl (A.S.) \\ 2 Department of Wood Science and Technology, Faculty of Forestry and Wood Technology, Mendel University \\ in Brno, Zemědělská 3, 61300 Brno, Czech Republic; gryc@mendelu.cz \\ * Correspondence: elzbieta.myskow@uwr.edu.pl
}

check for updates

Citation: Myśkow, E.; Sokołowska,

K.; Słupianek, A.; Gryc, V.

Description of Intra-Annual Changes in Cambial Activity and

Differentiation of Secondary

Conductive Tissues of Aesculus

hippocastanum Trees Affected by the

Leaf Miner Cameraria ohridella. Forests

2021, 12, 1537. https://doi.org/

10.3390/f12111537

Academic Editor: Veronica De Micco,

Angela Balzano, Arturo Pacheco

and Giovanna Battipaglia

Received: 13 September 2021

Accepted: 5 November 2021

Published: 8 November 2021

Publisher's Note: MDPI stays neutral with regard to jurisdictional claims in published maps and institutional affiliations.

Copyright: (c) 2021 by the authors. Licensee MDPI, Basel, Switzerland. This article is an open access article distributed under the terms and conditions of the Creative Commons Attribution (CC BY) license (https:// creativecommons.org/licenses/by/ $4.0 /)$.

\begin{abstract}
Aesculus hippocastanum trees are commonly infested by the leaf miner Cameraria ohridella, whose larval activity causes the destruction of the leaf parenchyma and induces defoliation. Pest attacks result in, e.g., production of smaller fruits and tree re-flowering in autumn. Concerning pest influence on stem structure only scarce information of narrower annual growth rings of wood has been published. Therefore, we determined the effect of the presence of the leaf miner infestation on intra-annual cambial activity and on differentiation of conductive tissues. These data were compared with phenological phases and pest activity. Pest feeding resulted in changes in onset, cessation and duration of cambial divisions, and differentiation of secondary xylem. The duration of cambial activity was about a month shorter in heavily infested trees and was connected with premature tree defoliation. Affected trees were characterised by a reduction in cambial divisions and earlier cessation of wood differentiation resulting in narrower wood rings. Furthermore, the infested trees exhibited altered wood structure, with more vessels of smaller diameters, however these changes did not affect its theoretical hydraulic conductivity. Interestingly, pest attack did not influence secondary phloem differentiation. The probable influence of long-term infestation on tree growth and condition was discussed.
\end{abstract}

Keywords: Gracillariidae; horse chestnut; infestation effects; leaf miner; phenology; secondary phloem; secondary xylem; vascular cambium

\section{Introduction}

The European horse chestnut, Aesculus hippocastanum L. (Sapindaceae), is native to the Balkan peninsula; however, due to its aesthetic properties, especially its large white inflorescences, it was brought to Europe in the 16th century, where currently it is one of the most recognisable trees, planted widely in the parks and thoroughfares of cities [1]. One of the naturally occurring pests of $A$. hippocastanum is the small leaf miner moth Cameraria ohridella Deschka and Dimić (Lepidoptyera: Gracillariidae) [2], which was identified for the first time in Macedonia in 1985 and then spread all over Europe [3]. The larva is the destructive stage of the pest, feeding on the parenchyma of the leaves and forming mines in the leaf blades. The infestation is repeated every year. Generally, the first mines are visible in May during flowering [3,4]. Heavily infested trees, due to the destruction of the leaf blades, lose their leaves prematurely and may produce new inflorescences in September, which leads to the inadequate preparation of the buds for winter dormancy and decreases the tree's resistance to frost [4-6]. Premature defoliation and a significant reduction in the area of the leaf blades result in reduced photosynthetic activity $[5,7,8]$. These changes are 
followed by the formation of lighter seeds and fruits, probably reducing the amount of nutrients available for the seedling during germination $[5,8]$. The latter assumption has been refuted as it has been shown that seed weight does not affect germination or the further development of horse chestnut trees [9]. Worth mentioning is that the changes in tree functioning, visible in late summer and autumn, are related to natural leaf senescence, and thus some authors state that the effects of $C$. ohridella feeding are not as destructive for the tree as generally believed [4,7]. Therefore, these results, which mainly concentrate on the tree functioning and physiology, are contradicting. Additionally, a detailed analysis of the influence of $C$. ohridella on the secondary thickening (secondary growth) of A. hippocastanum trees is lacking.

Secondary growth is a characteristic feature of trees and mainly results from the activity of cambium, a lateral cylindrical meristem, in which consecutive periclinal divisions form secondary xylem (wood) and phloem $[10,11]$. Wood is one of the most important natural resources, used by humans in everyday life and in many different branches of industry. Therefore, the activity of the meristem and the process of wood formation in trees are intensively studied on anatomical, physiological, and genetic levels [12-16]. The intra-annual changes of cambium activity and wood formation are examined in detail and also coupled with phenological observations [17-20]. Much less is known about the differentiation of the second conductive tissue, i.e., secondary phloem, in association with cambial activity, wood differentiation or tree phenology [20-25]. Moreover, cambial activity and the differentiation of secondary conductive tissues (especially wood) depend on many factors, both intrinsic (e.g., hormones and gene expression; [16,26]) and extrinsic (climatic and non-climatic; [27-31]). One of the non-climatic factors is the attack of defoliating insects, which can lead to a decrease in the width of growth rings as a consequence of fewer cambial divisions and fewer elements of secondary xylem thus being formed [32-34]. A decrease in the width of annual rings of horse chestnut trees as a result of $C$. ohridella attack has been shown [35-37]. This feature confirms the loss of fitness and lower growth range of the trees in growing season(s). However, the developmental mechanisms behind the formation of narrower annual rings in A. hippocastanum trees are unknown. This is because the studies of intra-annual changes in cambial activity and the differentiation of secondary conducting tissues are lacking. As a result, the impact of pests on tree functioning, and potential adaptation to long-term infestation, are not fully understood.

Therefore, we conducted accurate original analysis in the two-year period 2014-2015, with the aim of characterising the impact of horse chestnut leaf miner infestation on intra-annual cambium activity and the consecutive stages of the formation of secondary conductive tissues, both xylem and phloem, in relation to tree phenology. We hypothesised that intensive infestation of $C$. ohridella: (1) decreases the duration of cambium activity and the frequency of periclinal divisions; (2) affects the differentiation of secondary conductive tissues, both xylem and phloem; and (3) modifies the structure of secondary conductive tissues i.e., the size and number of vessels, resulting in changes to hydraulic conductivity. Developmental analyses of growth processes allowed us to better understand the impact of $C$. ohridella on A. hippocastanum and infer the long-term effects of pest infestation on tree functioning.

\section{Materials and Methods}

\subsection{Study Site}

The study was carried out in Wrocław, a city located $118 \mathrm{~m}$ a.s.l. in SW Poland. Wrocław has a temperate, mild climate characterised by a mean annual temperature of $9.7^{\circ} \mathrm{C}$ with the highest monthly mean $\left(19.7^{\circ} \mathrm{C}\right)$ and maximum $\left(25.6^{\circ} \mathrm{C}\right)$ temperatures in July and the lowest monthly mean $\left(0.0^{\circ} \mathrm{C}\right)$ and minimum $\left(-3.3^{\circ} \mathrm{C}\right)$ in January. The highest rainfall is in July $(92 \mathrm{~mm}$ ); however, precipitation is significant (about $550 \mathrm{~mm}$ ) throughout the year. The mean annual relative humidity is $76.3 \%$, with the highest $(85.5 \%)$ in November and the lowest (68.0\%) in April [38]. 
Fifteen horse chestnut trees, growing in five locations along roads and in parks of Wrocław, were chosen for analyses conducted in 2014 and 2015 (Figure 1, Table 1). All trees had been repeatedly attacked by the horse chestnut leaf miner, however with varied degrees of leaf blade destruction and the time of leaf shedding. Since it is known that leaf picking in autumn significantly improves the condition of trees and delays attack by the pest [39-41], two groups of trees differing in the degree of leaf miner infestation, were chosen for the analyses, on the basis of our preliminary few-year observations. The first group contained six lightly infested trees (LIT; Nos 1-6), whose fallen leaves were removed regularly every autumn. The second group constituted nine heavily infested trees (HIT; Nos 7-15) whose leaves had been falling precociously and were not removed. In both years, the LIT and HIT were sampled (Table 1; Table S1).

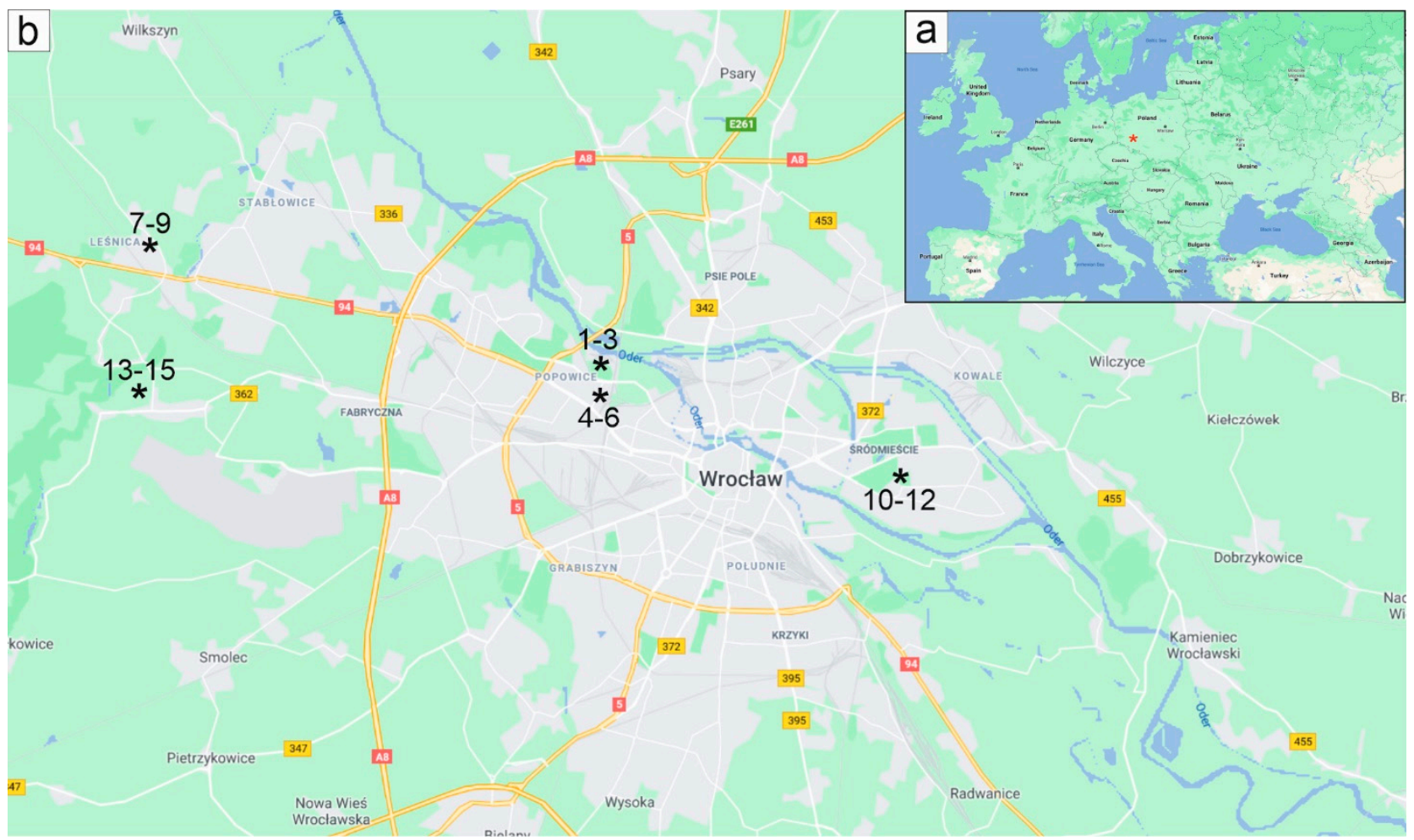

Figure 1. Map showing the location of the study area; (a) the city of Wrocław in a map of Europe; (b) magnification of Wrocław with the location of the study sites; sampling locations are marked by filled dots and analysed trees are numbered. Prepared using Google maps.

Table 1. Location of the analysed trees of A. hippocastanum sampled in 2014 and 2015.

\begin{tabular}{|c|c|c|}
\hline Year of Sampling & Lightly Infested Trees (LIT) & Heavily Infested Trees (HIT) \\
\hline 2014 & $\begin{array}{c}\text { trees 1-3 } \\
51^{\circ} 07^{\prime} 28.1^{\prime \prime} \mathrm{N} 16^{\circ} 59^{\prime} 44.8^{\prime \prime} \mathrm{E}\end{array}$ & $\begin{array}{c}\text { trees 7-9 } \\
51^{\circ} 08^{\prime} 53.4^{\prime \prime} \mathrm{N} 16^{\circ} 52^{\prime} 12.7^{\prime \prime} \mathrm{E} \\
\text { trees 10-12 } \\
51^{\circ} 06^{\prime} 35.7^{\prime \prime} \mathrm{N} 17^{\circ} 04^{\prime} 46.8^{\prime \prime} \mathrm{E}\end{array}$ \\
\hline 2015 & $\begin{array}{c}\text { trees 4-6 } \\
51^{\circ} 07^{\prime} 28.1^{\prime \prime} \mathrm{N} 16^{\circ} 59^{\prime} 44.8^{\prime \prime} \mathrm{E}\end{array}$ & $\begin{array}{c}\text { trees 13-15 } \\
51^{\circ} 08^{\prime} 01.4^{\prime \prime} \mathrm{N} 16^{\circ} 50^{\prime} 50.6^{\prime \prime} \mathrm{E}\end{array}$ \\
\hline
\end{tabular}

In consideration of the high similarity of the results obtained in 2014 and 2015, these data were treated collectively for the two-year period, both for the lightly and for the heavily infested trees. 


\subsection{Phenological Observation}

The phenological phases considered were the following: dormant; bud swelling; leaf emerging; full leaf unfolding; flowering; chestnut appearing; mature fruit; and leaf fall [42] and they were observed concomitantly with micro-core sampling. The phenology of the trees was documented photographically and the degree of infestation as a result of larval activity of $C$. ohridella was monitored in two different groups of trees, LIT and HIT. Three different stages of infestation were recognised: (1) the first small mines appear; (2) the majority of leaf blades are green, but with long mines; (3) numerous mines, majority of leaf blades are brown; dry leaflets are falling.

\subsection{Sampling Methods, Preparation of Slides and Microscopy}

Nine trees in 2014 and six trees in 2015 (Figure 1, Table 1) were sampled using the Trephor tool [43] weekly from the beginning of April to the middle of May and then in two-week intervals to the middle of October. In total, each tree was sampled 17 times per year and at every time point, two micro-cores were taken from each tree. Finally, 510 micro-cores were collected, 204 from LIT and 306 from HIT. The successive samples were taken along a helix winding around the tree stem, at a distance of 1.20 to $1.60 \mathrm{~m}$ above the ground. To facilitate micro-core sampling, the rhytidome was removed; the micro-cores sampled contained cambium, and secondary xylem and phloem differentiated in recent years $[13,44]$. The samples were immediately fixed in FAA (formalin-acetic acidalcohol) for a week, moved to $50 \%$ ethanol and then dehydrated in a tertiary butyl alcohol series $(50 \%, 70 \%, 90 \%, 95 \%$, three times $100 \%$; $1.5 \mathrm{~h}$ per solution), infiltrated in the butyl alcohol-paraffin solution (20\%, 40\%, 60\%, $80 \%$ and $100 \%$; $1.5 \mathrm{~h}$ per solution) and then embedded in paraffin [45]. From each micro-core, a series of transverse sections, 8-10 $\mu \mathrm{m}$ thick, were prepared using a rotary microtome (Leica RM 2135, Leica Instruments GmbH, Wetzlar, Germany). Sections were kept in xylene (three times per $10 \mathrm{~min}$.) to dissolve paraffin, double stained with a Alcian Blue-safranin $\mathrm{O}$ mixture, dehydrated in ethanol (50\%, 70\%, 90\% and 100\%; 2 min. per solution), kept in isopropanol (three times $10 \mathrm{~min}$ ) and embedded in Euparal [45].

Microscopic sections were observed in bright field under an Olympus BX50 microscope equipped with an Olympus DP71 camera and Cell B software (Olympus Optical Co., Warsaw, Poland). A polarising adapter was used to detect the formation of secondary cell walls in differentiating cells. CorelDraw 2017 (Corel Co., Ottawa, Canada) was used to prepare the figures.

\subsection{Cambium Activity and Formation of Secondary Conductive Tissues}

Intra-annual analyses were made on the basis of the transverse sections cut from each micro-core sampled during the growing seasons from the trees under study. For each tree and for each micro-core, the number of cambial cells in a radial row was counted in at least three randomly selected radial files according to the procedure in Oladi et al. [46]. The cells characterised by a rectangular shape, small radial dimension and thin cell walls were identified as cells of the cambial zone. In dormant cambium, the border between xylem and cambium was easily distinguished by the difference in thickness of the cell walls of xylem cells (thick cell walls) and cambial cells (thin cell walls). The border between cambium and phloem was established based on the presence of undifferentiated overwintering derivatives on the phloem side, which were characterised by oblique cell walls of justformed companion cells [47]. As the companion cells were visible during the entire year, the border between cambial and phloem cells was easily distinguishable. The beginning of cambial activity was determined by the periclinal divisions visible due to thin divisional walls in cambial cells resulting in an increased number of cambial cells in the radial files. The lack of periclinal divisions, and a decrease in the number of cells in a radial row, indicated the cessation of cambial activity.

Concomitantly, the number of wood cells formed in each year was counted. This was calculated as the number of fibres in a radial file, except the file where the vessel 
interrupted the fibre arrangement. In such a case, the fibres in an adjacent radial file were numbered. The cells in three randomly selected radial files were counted [46]. Successive steps of xylem cell differentiation were distinguished: (1) postcambial growth zone was indicated by a two-fold increase in the radial dimension of the wood cells; (2) the beginning of secondary cell wall deposition was designated by the birefringence of the cell wall under polarised light; (3) lignification of the cell walls was detected by red staining by safranin, which was followed by the further maturation of the cells. Stages of wood formation were designated and analysed according to Oladi et al. [46], Marion et al. [13], Giagli et al. [44] and Gričar et al. [42].

Concomitantly with the analyses of wood differentiation, the formation of secondary phloem was analysed. The number of cells in radial rows, as well as their identity (sieve elements, parenchyma or fibres) were determined and counted during the year.

\subsection{Measurements and Statistical Analyses}

For each tree, additional measurements were made on transverse sections from the micro-cores sampled at the end of the growing season. Thus, the wood from the most recent annual growth ring was analysed. The width of the last annual growth ring was measured; five measurements were made for each annual ring. Additionally, the number of vessels per $\mathrm{mm}^{2}$ and the mean vessel lumen area were calculated. A minimum of $1.5 \mathrm{~mm}^{2}$ of secondary xylem surface and at least 300 vessels were analysed per tree. In all cases, the surface was chosen to contain both early and latewood from the cambium to the border of the annual ring of wood. AxioVision software (Carl Zeiss Vision GmBH, Göttingen, Germany) was used for all of the measurements.

To check whether changes in the wood structure result in the modification of water transport efficiency, we measured the theoretical hydraulic conductance (THC, $\left.\mu \mathrm{m}^{2}\right)$. A minimum area of $0.6 \mathrm{~mm}^{2}$ was analysed, and the minimum and maximum diameters of lumens of all vessels (at least 80 for each tree) were measured [48]; and the radius of each vessel was calculated. According to the Hagen-Poiseuille equation [49], THC is a sum of the fourth power of the vessel radius divided by the area [50]. The values were calculated for each tree and the average value was calculated for both groups of trees, i.e., LIT and HIT.

All the measurements were tested for normality and the homogeneity of variances by means of the Shapiro-Wilk W-test and Leven's test, respectively. Welch's $t$ test was used to correct any unequal variances between groups. The differences between the groups of trees were compared using a t-test. The widths of annual growth rings did not have a normal distribution in Shapiro-Wilk test $(\alpha<0.05)$, thus the significance of the differences was checked using the U Mann-Whitney test [51]. Data analyses were conducted in Statistica 13 software (StatSoft, Inc., Tulsa, OK, USA, 2014).

\section{Results}

\subsection{Phenological Changes and Horse Chestnut Miner Infestation}

In both groups of trees studied, phenological changes proceeded similarly during the year (Figure 2a-g). Until the end of March, the buds were dormant (Figure 2a). They swelled in the first third of April (Figure 2b), only one location (Nos 1-3) swelled one week earlier in 2014; and after one week the first pair of leaves appeared (Figure 2c). At the end of April, the first flowers opened, although, as previously in the same group of trees (Nos 1-3) one week earlier; full flowering occurred at the beginning of May in all trees (Figure 2d). Blooming lasted 2-3 weeks, till the end of the second third of May. The fruits started to appear in the second half of May (Figure 2e); in one group of trees (Nos 13-15) in 2015, this stage was observed one week later. The fruits matured until autumn (Figure 2f). During September, mature fruits fell, both in lightly infested (LIT) and heavily infested (HIT) trees. The process of leaf senescence was significantly different in the LIT and HIT. In the LIT, the leaves turned yellow and brown (Figure $2 \mathrm{~g}$ ) and fell from the beginning of September to the middle of November in both years under study. In contrast, in the HIT, 
the process of leaf senescence and drying started at the beginning of August and leaves fell until the middle of October.
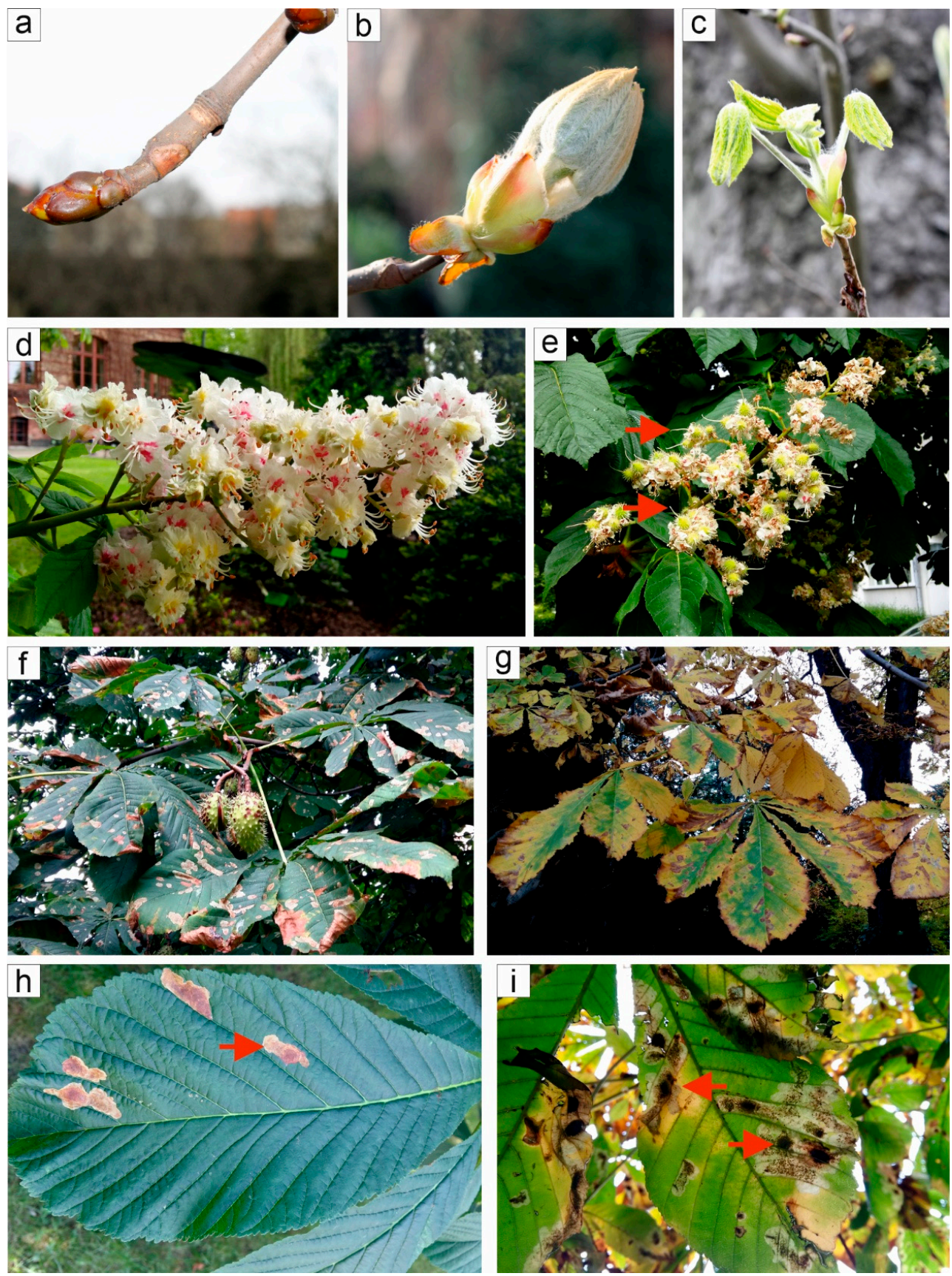

Figure 2. Annual changes in phenology and horse chestnut miner infestation on Aesculus hippocastanum during the year. (a) dormant bud; (b) bud swelling; (c) the emergence of the first leaves; (d) flowering; (e) formation of the first fruits, the remnants of pistils are still visible (arrows); (f) the mature fruits; (g) brownish and yellowish leaves in autumn; (h) stage 1; the first mines formed in the leaf as a result of the larvae feeding (arrow); (i) stage 2; more destroyed leaf with more mines (arrows).

The first mines associated with larvae feeding in the leaf parenchyma were observed in LIT in the middle of June (Figure 2h; Stage 1 in Table S1), while in HIT this was seen about three weeks or a month earlier (in the second third of May). During the growing season, the process of leaf destruction continued (Figure 2i; Stages 2 and 3 in Table S1) and 
was more intense in the HIT, leading to precocious defoliation. The leaf miner attacks have been observed every year.

\subsection{Activity of Cambium}

The duration of the cambial activity was estimated on the basis of the occurrence of cambial cell divisions and of the changes in the number of cambial cells in radial rows.

In both analysed groups of trees, cambium was dormant with 5-8 (average 6.5) cells in a radial row till the first third of April, (till the 95 day of the year (DOY); Figure 3a,e). The cambium became active on 12th April (102 DOY), which was marked by the first divisions in cambial cells (Figures $3 \mathrm{~b}$ and 4 ). At the same time, the first leaves appeared. As a result, the number of the cells in radial rows started to increase (Figure 3e). In the LIT, the tendency of increasing cell numbers was maintained during the growing season, reaching about 11-12 cells in a radial row from the end of May to the beginning of August (144-214 DOY; Figure 3c,e). In this group of trees, the cambium remained active until the second half of August (228 DOY), then divisional activity ceased and the number of cambial cells in radial rows decreased to nine (Figure $3 \mathrm{~d}$,e and Figure $4 \mathrm{a}$ ). In contrast, in the HIT, after the onset of cambium activity at the beginning of April, the number of cambial cells in radial rows increased slowly, reaching a maximum (about 10-11 cells) on 5th July (158 DOY; Figures 3e and 4b). Then, the number of cells decreased concomitantly with the progressive destruction of leaf blades due to leaf miner feeding. The last periclinal divisions, indicating the cessation of cambium activity, were observed in the middle of July (200 DOY; Figure 4b), which was followed by precocious leaf senescence. During the entire growing season, the average number of cambial cells in radial rows was lower in HIT than in LIT (Figure 3e).

\subsection{Formation and Structure of Secondary Xylem}

During our studies, successive stages of wood cell differentiation produced during the growing season were analysed in A. hippocastanum trees (Figure 5).

In both groups of trees examined, after the beginning of cambium activity (102 DOY) almost to the end of April (116 DOY), new secondary xylem cells were not established (Figures 4 and 5a). From this time, and throughout the growing season, new wood cells were constantly formed as a result of divisional activity in the cambium and the continuing process of differentiation (Figure $5 b, c$ ). The first evidence of wood cell differentiation was visible as an increase in the length and width of cells, termed the postcambial phase, that occurred in the LIT about two weeks after the first divisions in the cambium, i.e., in the last third of April (116 DOY; Figures 4a and 5b). In HIT, the process of wood differentiation started one week later, at the beginning of May (123 DOY; Figure 4b). The number of wood cells formed in the current year increased significantly coinciding with the end of flowering, from the middle of May (137 DOY); however, this increase was more pronounced in the LIT than in HIT (Figure 5c). Approximately four weeks after the appearance of the first wood cells, the deposition of the secondary cell wall and the processes of lignification and cell maturation were observed simultaneously in both groups of trees (Figures 4 and $5 \mathrm{~d}-\mathrm{g}$ ).

At the end of the growing season, concomitantly with the decrease in cambium activity, the previously formed xylem cells continued the process of differentiation, and the immature cells were still visible after two weeks, i.e., at the end of August in the LIT (242 DOY; Figure 4a). In HIT, the last periclinal divisions and differentiated xylem cells were observed in the middle of July (200 DOY), but two weeks later (first days of August) all cells were mature. It should be added that these stages were observed concomitantly because of the two-week intervals between taking the micro-core samples. Therefore, in August LIT still showed cambial activity and the continuing processes of xylem differentiation (Figure 5h), whereas at the same time the process of differentiation was almost entirely finished in HIT (Figure 5i). 

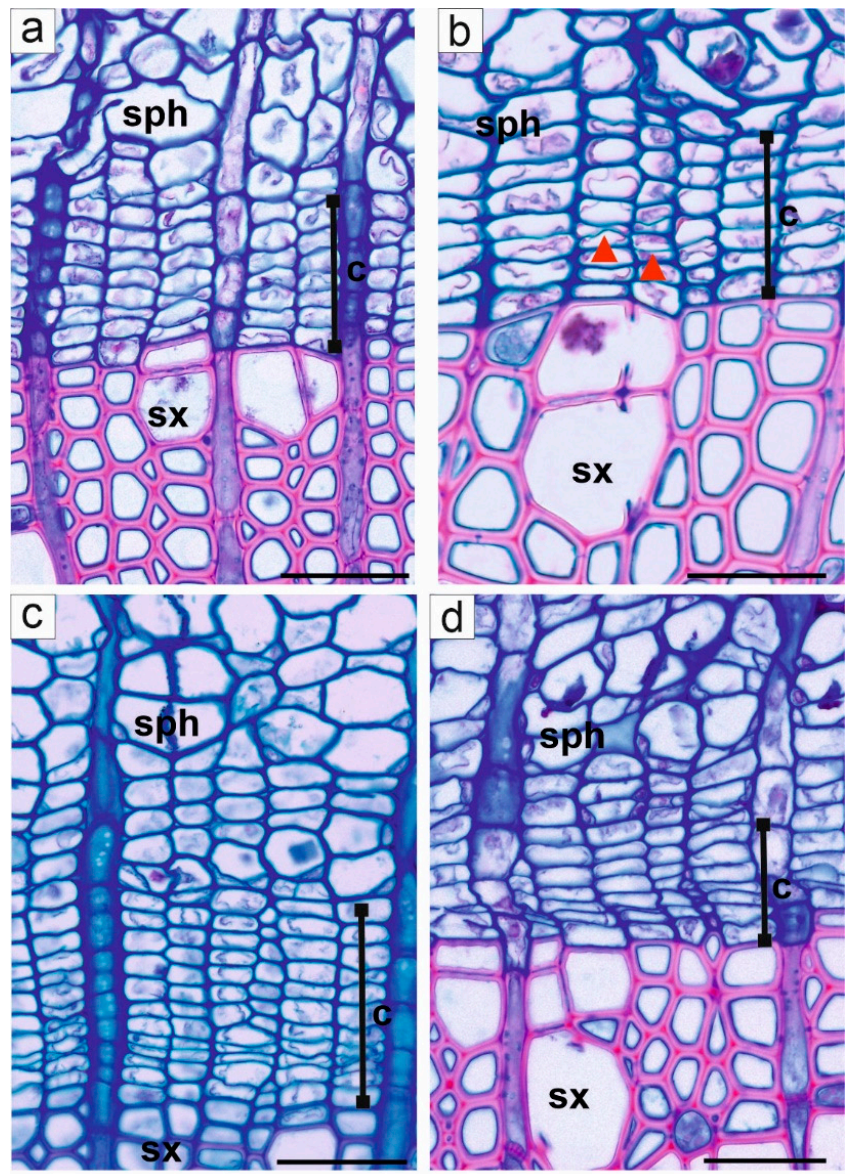

e

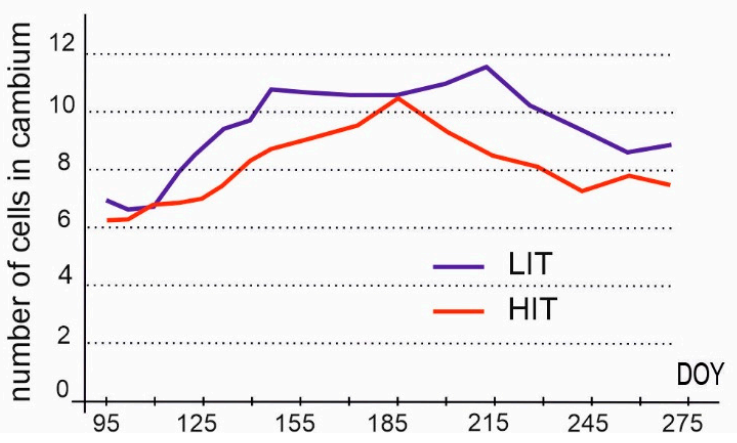

Figure 3. Intra-annual changes in cambium activity of Aesculus hippocastanum trees under the impact of horse chestnut leaf miner. (a-d) transverse sections; (a) dormant cambium (denoted by bracket) with 5-8 cells located in radial files at the beginning of April; (b) the onset of cambium activity in the middle of April, periclinal divisions in cambial cells are visible (arrowheads); (c) the peak of cambium activity with 11-12 cells in radial rows in July; (d) cessation of cambium activity characterised by a lack of periclinal divisions and a decrease in the number of cells in radial rows; shown in September; (e) changes in the mean number of cambial cells during the growing season (DOY - day of the year) showing the difference between lightly (LIT) and heavily infested (HIT) tress; the mean number of cambial cells increased in both groups of trees in April, which coincides with the beginning of divisional activity of the meristem; the decrease in cell number was determined in the middle of July in HIT, whereas in LIT it was in August. The microphotographs are taken from one LIT to show the changes observed during the season. c cambium, sph-secondary phloem; sx-secondary xylem. Scale bars $50 \mu \mathrm{m}$.

Eventually, trees, from both analysed groups-LIT and HIT-significantly differed in the number of wood cells formed during the year (Figure 5c). In the LIT, during the 
growing season 110-120 cells (counted in a radial row) were formed, in striking contrast to the 20-25 cells counted in the HIT trees (Figure $5 \mathrm{c}$ ). This unevenness in the number of wood cells formed during the year caused significant differences in the widths of the annual wood rings between the LIT and HIT; the average width in the LIT was $2107.5 \mu \mathrm{m}$ (with a range of 1211-2725 $\mu \mathrm{m}$; Figure 5j,1), whereas in the HIT the width reached only $417.9 \mu \mathrm{m}$ (with a range of $121-924 \mu \mathrm{m}$; Figure $5 \mathrm{k}, 1$ ). The U Mann-Whitney test proved the significant statistical difference $(Z=-7.26, p<0.05$; Figure 51$)$ of this parameter between both groups of trees.

To better understand differences in the impact of the pest on the formation of secondary xylem elements, we compared the wood structure of the two studied groups of trees. The analysis of the number of vessels per $\mathrm{mm}^{2}$ showed (Figure $5 \mathrm{~m}$ ) that, in the LIT, there were on average 161.4 vessels per $\mathrm{mm}^{2}$ (min.-max. amount to 112.9-215.2), whose vessel area was $1377.8 \mu \mathrm{m}^{2}$ (with a range of 173-2848). In comparison with the LIT, the HIT showed an increased average number of vessels that reached 219.8 per mm$~_{2}$ (with a range of 146-330.5) but the mean vessel area was smaller, i.e., $1270.8 \mu \mathrm{m}^{2}$ (with a range of 127.1-3260.3). The differences between the analysed groups of trees were found to be statistically significant using the t-test (Figure $5 \mathrm{~m})$, both in the number of vessels $(\mathrm{F}=118.77, p<0.05)$ and in the vessel area $(\mathrm{F}=8.69, p<0.05)$. Next, to examine the possible changes in water transport efficiency, the theoretical hydraulic conductance (THC) was calculated from the vessel lumen diameter. Surprisingly, the two groups of trees showed similar mean values of THC-i.e., $30.49 \mu \mathrm{m}^{2}$ (with a range of 14.88-44.56) in LIT and $30.66 \mu \mathrm{m}^{2}$ (with a range of 17.39-51.64) in HIT.
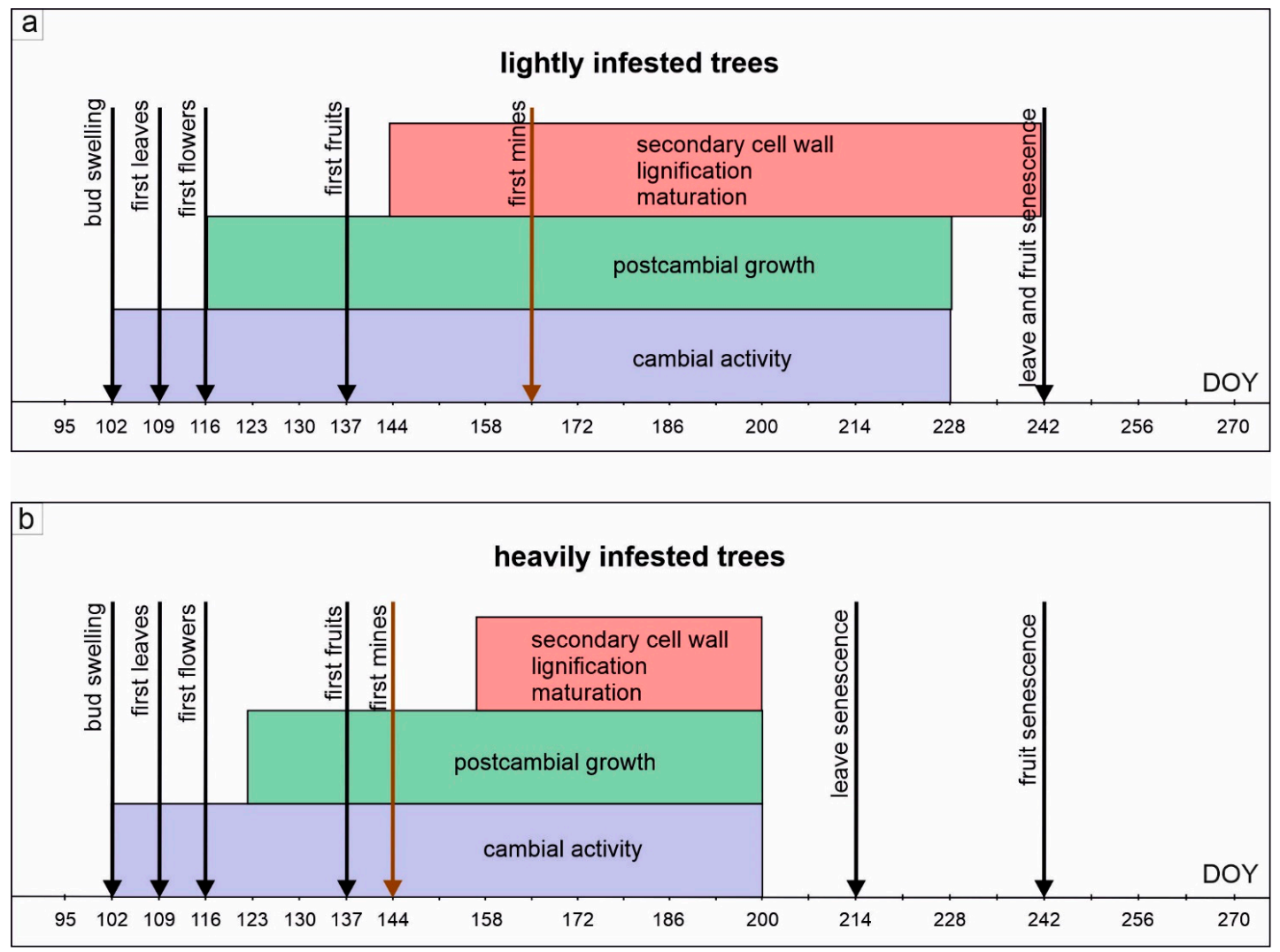

Figure 4. The duration of cambium activity and of successive stages of differentiation of secondary xylem cells in lightly (a) and heavily infested (b) trees of Aesculus hippocastanum. The length of the rectangles indicates the mean onset and cessation of the analysed stages during the year. The vertical lines indicate the dates when the successive phenological stages and symptoms of horse chestnut infestation was observed. In HIT, the duration of cambium activity was shortened by about one month, which resulted in the shortening of the successive stages of wood differentiation. This shortening can be attributable to the difference in the level of infestation of the previous years; DOY-day of the year. 

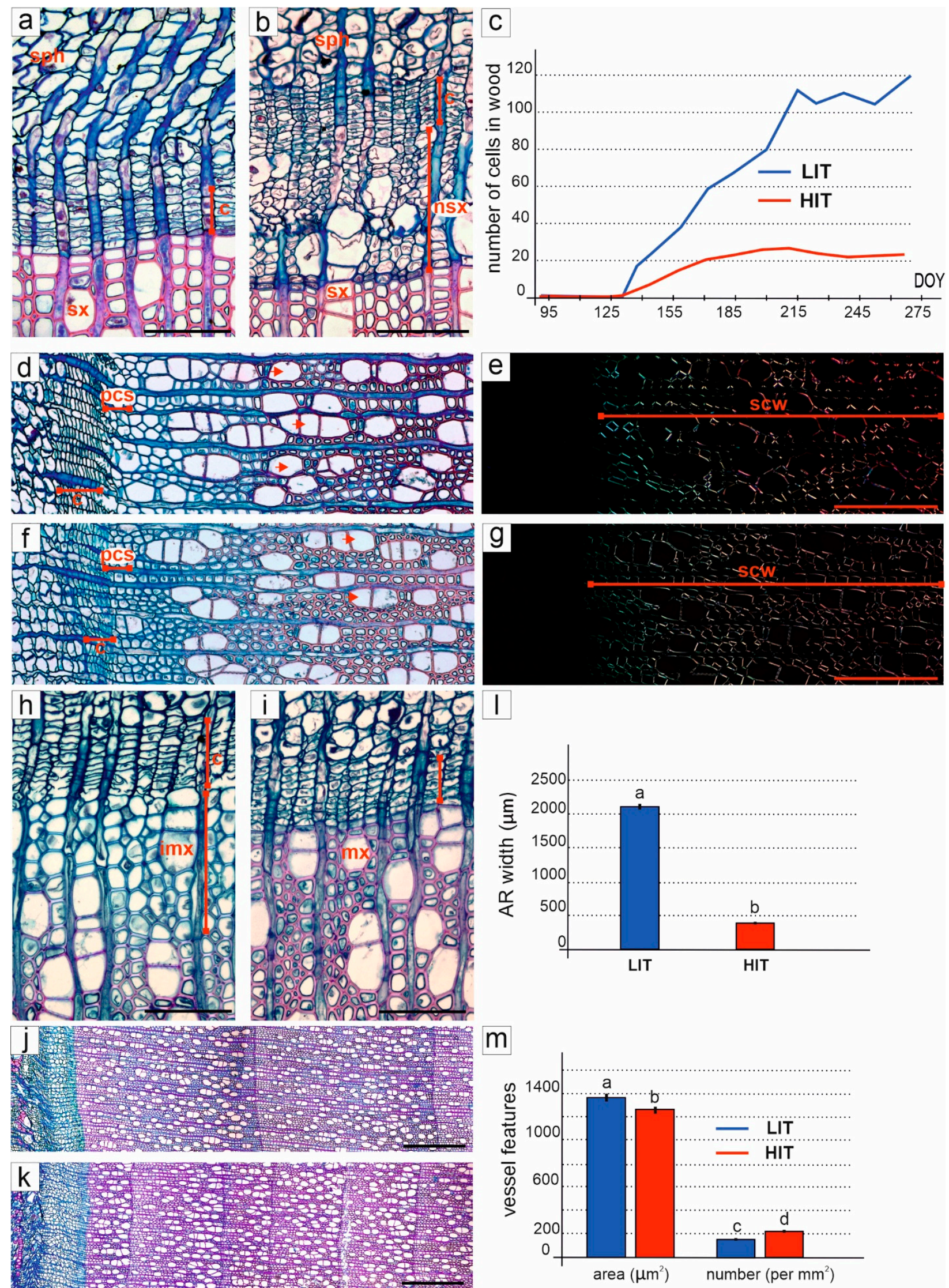

Figure 5. The impact of Cameraria ohridella on the differentiation and structure of secondary xylem in Aesculus hippocastanum trees. (a,b), (d-k) transverse sections; (a) cambium (c) and secondary conductive tissues in April after initiation of cambium 
activity in HIT; only the entirely differentiated secondary xylem (sx) cells formed in previous year are visible; new cells from current year are absent; (b) LIT, new secondary xylem cells (nsx) formed in current year are clearly visible in June; (c) changes in the mean number of secondary xylem cells produced during the growing season in the LIT and HIT; DOYday of the year; $(\mathbf{d}-\mathbf{g})$ successive stages of wood differentiation shown on cross-sections under bright-field illumination $(\mathbf{d}, \mathbf{f})$ and polarised light $(\mathbf{e}, \mathbf{g})$ in LIT $(\mathbf{d}, \mathbf{e})$ and HIT (f,g), cells located close to the cambium in postcambial stage (pcs) and secondary cell wall (scw) are visible in polarised light (e,g); lignification of cell walls indicated by the red colour; mature cells denoted by arrows; (h) LIT, immature secondary xylem (imx) cells are still visible in August indicating that the process of differentiation is in progress; (i) HIT in August; the process of differentiation of secondary xylem is almost finished, only one layer of cells is not mature $(\mathrm{mx}) ;(\mathbf{j}, \mathbf{k})$ a general view of the last formed annual rings of wood in LIT (j) and HIT (k); the significantly narrower rings occurred in HIT; in both pictures last formed annual ring corresponds to 2015; (1,m) the difference in the structure of wood in the width of annual rings (AR) of wood (1) and the vessel number and vessel area (m); the significant differences in values between LIT and HIT are denoted by lower case letters; standard errors are indicated by whisker plots. Each photo is taken from the most explanatory sample of the LIT and HIT; Bars: $(\mathbf{a}, \mathbf{b}, \mathbf{h}, \mathbf{i}) 100 \mu \mathrm{m} ;(\mathbf{d}-\mathbf{g})$ $200 \mu \mathrm{m} ;(\mathbf{j}, \mathbf{k}) 500 \mu \mathrm{m}$.

\subsection{Formation and Structure of Secondary Phloem}

The process of secondary phloem differentiation was similar in LIT and HIT. The subsequent stages occurring during the process of phloem differentiation could be followed due to the presence of characteristic flattened cells formed during the second half of the growing season. These flattened cells formed a layer which was either regular or continuous, in both cases sufficiently visible to trace the changes that had occurred (Figure 6a). In both groups, the first modifications related to the differentiation of secondary phloem were first observed at the beginning of April (95 DOY), before the first divisions in the cambium (Figure 6a). At this stage, 2-3 sieve tubes with adjacent companion cells, which had been produced in the previous year, were visible in the neighbourhood of the cambium. In both groups of trees, in the second third of April (109 DOY), as the divisions appeared in the cambium (Figure 4), the newly produced cells were first added on the phloem side, although no derivatives were formed on the wood side of cambium (Figure $6 \mathrm{~b}$ ). At the beginning of April, flattened cells were located at a distance of 3-4 cells from the cambium (Figure 6a), and, two weeks later, after the formation of new phloem cells, they were pushed away from the cambial zone to a distance of 5-7 cells (Figure $6 \mathrm{~b}$ ). In the following months, several secondary phloem cells originated, so that, finally, 11-13 phloem cells were visible in both groups of trees (Figure 6c). In mid-July (200 DOY), 2-3 new layers of flattened cells, produced in the current season, were recognised, as well as new sieve tubes with companion cells which would overwinter in an undifferentiated form (Figure 6d).

As the phloem cells moved away from cambium, sieve tube elements (two years old) that were located more distant, lost their conducting function and were modified into fibres (Figure 6e). Concomitantly, some parenchyma cells enlarged significantly (Figure 6e,f). In older layers of phloem, formed in the previous consecutive years, more and more cells transformed into fibres (Figure 6e,f). 

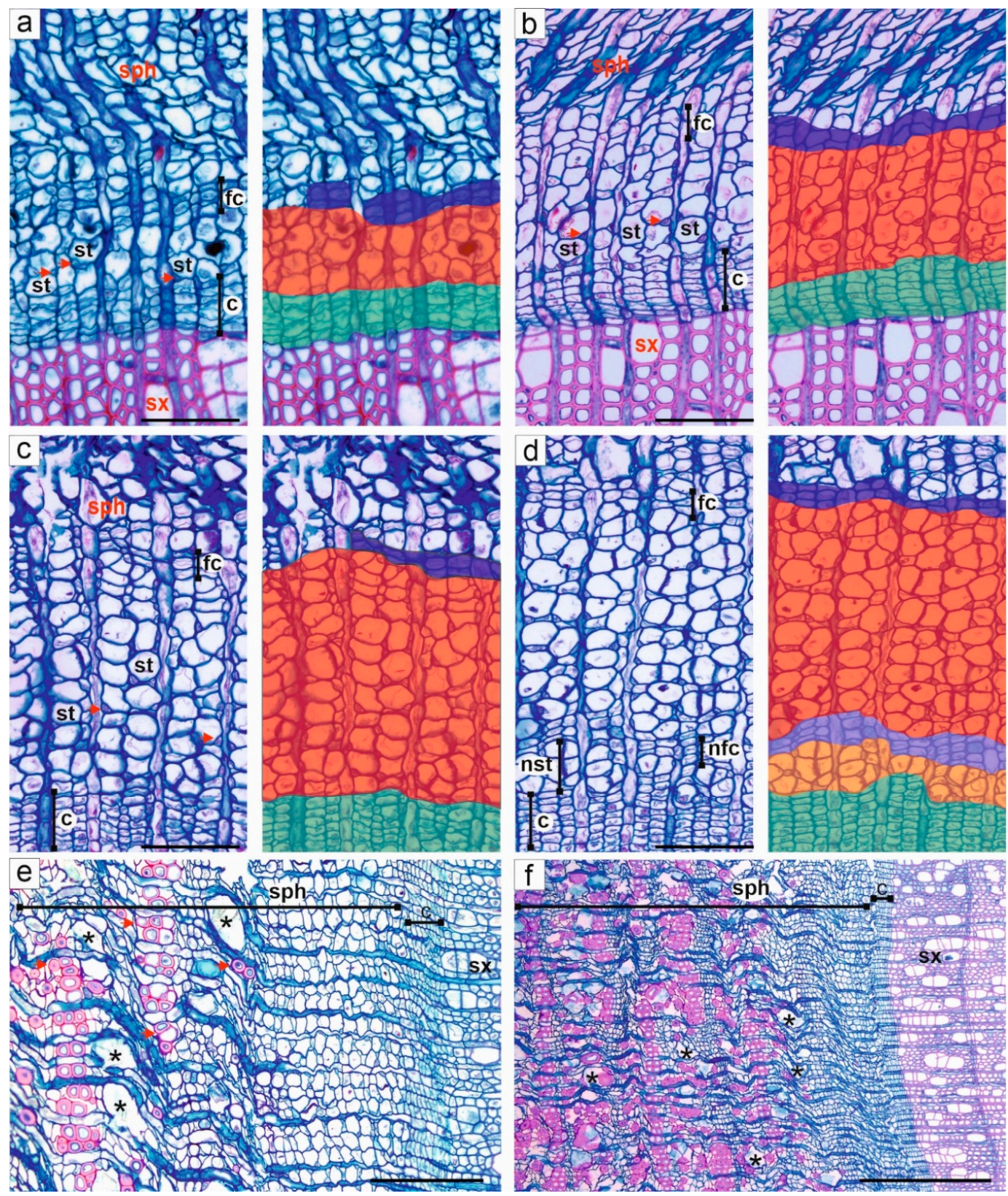

Figure 6. Intra-annual changes in secondary phloem differentiation presented on transverse sections of Aesculus hippocastanum. (a-d) successive stages of secondary phloem development (left panels) and interpretation of the stages (right panels); (a) 5 April (95 DOY; day of the year); HIT, in the neighbourhood of dormant cambium (c, filled with green); sieve tubes (st, filled with red) with characteristic companion cells (arrows), which were formed in the previous year, are clearly visible; the flattened cells (fc, filled with blue) are located 3-4 cells from the cambium; (b) 19 April (109 DOY); LIT, as the result of the onset of cambium activity (c, filled with green) new sieve tubes (st) are formed (the region of conductive cells filled with red) thus the flattened cells (fc, filled with blue) are moved away from the cambium; at this time, no secondary xylem cells have been formed; (c) 21 June (172 DOY); LIT, further formation of secondary phloem cells (the region of conductive cells filled with red) resulted in flattened cells (fc, filled with blue) moving away; (d) 19 July (200 DOY); LIT, formation of new flattened cells ( $\mathrm{nfc}$, filled with light blue) in current year; flattened cells $\left(\mathrm{fc}_{\mathrm{c}}\right.$ ) originated in previous year are filled with blue; near the cambium (c, filled with green) new sieve tubes (nst, filled with light red) originated; (e-f) mature secondary phloem; in non-conducting secondary phloem sieve tubes are modified into fibres (arrows), whereas some parenchyma cells have enlarged significantly (asterix). Each photo is taken from the most explanatory sample of LIT or HIT. Bars: (a-d) $100 \mu$ m; (e) $200 \mu \mathrm{m}$; (f) $500 \mu \mathrm{m}$. 


\section{Discussion}

The negative impact of leaf miner infestation on the condition of A. hippocastanum trees have been observed for many years, undoubtedly, also due to the aesthetic value of the trees of this species $[5,8,39]$. Nevertheless, developmental, and anatomical studies of secondary conductive tissues coupled with tree phenology are lacking. We present here a new approach to analyse and relate the influence of $C$. ohridella on the functioning of the tree and to broaden our knowledge in the subject and deduce possible mechanisms of tree response and adaptation to pest attack.

The developmental processes, i.e., cambium activity and the further formation of secondary conductive tissues, are closely integrated and correlated with phenological changes. These processes, together, are deeply embedded in the tree's annual growth cycle. As we have shown, in A. hippocastanum the onset of cambium activity was correlated with bud swelling similarly to other diffuse porous trees [52]. In trees, the leaves are the site of photosynthesis, and the source of photoasymilates and auxin necessary to maintain meristem activity during the entire growing season [53]. These factors have a crucial influence on the process of differentiation of conductive tissues [15,54,55]. At the end of the growing season, concomitantly with leaf senescence and decreasing rates of photosynthesis and auxin transport capacity [56], the cambial initials decrease and ultimately stop dividing. During this time, cells formed earlier finish the process of differentiation $[53,55]$. Since the processes related to conductive tissue formation are energy-consuming, we showed that they differed significantly in trees growing under prolonged and repeated pest infestation. In heavily infested horse chestnut trees (HIT), the period of cambial activity was about a month shorter than in lightly infested trees (LIT) and was probably related to the every year repeat of the significant infestation of trees by $C$. ohridella, leading to the reduction or absence of leaves already in September. The significant shortening of cambial activity resulted in the formation of narrower annual rings of wood. This has been also previously shown for infested chestnut trees [35-37], in which the narrower wood rings were formed during consecutive years. These results are in contradiction to the data presented so far that were related to seasonal events, after which the trees returned to their previous condition or could even increase their growth rate $[33,34,57]$. The phenomenon of reduced cambium activity is generally considered to be a tree's response to extreme environmental factors such as drought, fire, frost, flooding, environmental pollution, or urban habitat $[13,29,31,58,59]$. Eventually, the cessation of cambium was observed as a result of significant stress, e.g., stem girdling [60]. Additionally, it seems that the shortening of cambium activity, and thus the formation of narrower rings of wood, is one of the first responses of the tree to extremely negative environmental factors, especially if it is associated with significant or complete defoliation $[13,44]$. However, trees can react differently to a leaf miner outbreak. Interestingly, in Italy [61], Aesculus trees formed wider annual growth rings, which was related to the formation of false rings, i.e., the re-formation of early wood. Additionally, this wood was characterised by a larger number of vessels with a larger diameter. The authors pointed out that trees increased the production of wood and hydraulic efficiency to improve the transport of water to the leaves and increase the rate of photosynthesis, thus compensating for the earlier defoliation [61]. In contrast, in our studies performed on trees at more northerly latitudes than Italy, different modifications in the structure of secondary xylem were observed in chestnuts. We showed that HIT formed more vessels with smaller mean diameters than LIT. Surprisingly, similar mean values of THC calculated for both groups of trees, indicated a lack of change in hydraulic efficiency. This suggests that a shorter period of cambium activity and the formation of thinner annual wood increments can probably be compensated by adjusting the structure of the wood in order to maintain transport at a similar level. On the other hand, this may be the result of prolonged leaf miner presence and tree adaptation to the stressing factor. Thus, our results are contradictory to the earlier data presented by Salleo et al. [61]. Additionally, it is known that modifications in wood structure, similar to observed in Aesculus trees, are common for gymnosperms and other angiosperms and can alter the mechanical properties of wood $[33,62,63]$. It seems 
possible that prolonged and repeated infestation may weaken trees in long-term projection, resulting in an increase in their frangibility, loss of vitality and ultimately the decrease in the aesthetic values of these ornamental species.

In diffuse-porous trees, the first single cells of wood are formed when the leaves developed on the branches [10,52]. This was also observed in both groups of analysed chestnut trees. However, a significant increase in wood formation was noted almost one month after the onset of cambial activity, similarly to what was previously found in A. hippocastanum and Fagus sylvatica [17,47]. It seems to be worth stressing, since the time of the pest attack during the season is of importance for the tree's condition, if the outbreak occurs later in the summer, the changes are visible only in latewood and are supposedly not so harmful $[54,57]$. Therefore, it was suggested that defoliation in summer is not a reason for chestnut dieback $[4,5,40]$ and does not affect the radial tree growth which takes place mainly in the first part of the growing season [36]. It seems probable that repeated outbreaks of the leaf miner result in a decrease in the accumulation of nonstructural carbohydrates (NSC) and an overall slowdown in the radial growth due to decreased formation of narrower rings and, therefore, the general fitness and vitality of the entire tree $[14,32,37,64-67]$. Moreover, it is known that long-term stress, especially when connected to partial or complete defoliation, influences the entire tree physiology and functioning, as well as reducing its resistance to other stresses (e.g., drought or pathogens as Guignardia aesculi) and hindering recovery $[36,58,68,69]$. Therefore, it is worth stressing, that probably the adjustments observed in HIT, such as, e.g., shortening of the duration of cambial activity and formation of narrower rings of wood, do not result directly from the precocious defoliation in the current growing season, since, e.g., the reduction in the number of xylem cells was observed already from the beginning of the growing season.

Interestingly, the feeding of the leaf miner did not affect the formation and differentiation of secondary phloem, although we expected such changes as a result of reduced production of assimilates due to earlier defoliation. As we showed, the differentiation of the first phloem elements began before the first divisions in cambium and successive steps of phloem formation were in accordance with observations by Barnett [47] of Aesculus hippocastanum, as well as with other species $[17,24,70]$. The lack of visible changes in secondary phloem differentiation between the LIT and HIT is in accordance with earlier studies, in which trees growing under stress conditions formed narrower annual increments of wood, while the formation of phloem was not changed [21,66], thereby indicating that the regulation of phloem differentiation depends more on internal than external factors [24].

To conclude, we revealed that prolonged and repeated attacks of the horse chestnut leaf miner may be followed by precocious cambium cessation and, thus, the formation of narrower and structurally modified annual wood increments. It is worth stressing that these modifications observed in HIT probably do not directly arise from the precocious defoliation in current growing season, but are the effect of prolonged and repeated every year defoliation. Oppositely, it seems that, leaf miner outbreak does not affect secondary phloem differentiation. We suspect that observed modifications of wood structure may cause the decrease in the mechanical properties of wood, contributing to a greater fragility. Moreover, partial, or complete leaf blade destruction by the pest during the growing season can induce NSC pool decline, which could additionally cause the tree to be more susceptible to other biotic and abiotic factors. Altogether, in long-term projections, affected trees not only significantly lose their aesthetic values, but infestation may negatively impact their fitness and increase their liability to breaking and mortality.

Supplementary Materials: The following are available online at https:/ /www.mdpi.com/article/10 $.3390 / \mathrm{f1} 2111537 / \mathrm{s} 1$, Table S1: The degree of infestation of Aesculus hippocastanum trees as a result of Camararia ohridella larval activity.

Author Contributions: E.M. and V.G. with the help of K.S. developed the study conception; E.M. and V.G. with the help of K.S. implemented the methodology; E.M. and K.S. collected and analysed the data with the help of A.S.; A.S. measured the wood characteristics and THC.; all authors interpreted 
the data; E.M. prepared the figures; E.M. wrote the manuscript with the help of K.S., V.G. and A.S. All authors have read and agreed to the published version of the manuscript.

Funding: This study was funded by the Polish Ministry of Higher Education, Grant no. 501/73/ZBRR/21. V.G. was supported from the European Union's Horizon 2020 research and innovation programme under grant agreement No. 952314.

Institutional Review Board Statement: Not applicable.

Informed Consent Statement: Not applicable.

Data Availability Statement: Not applicable.

Acknowledgments: We would like to thank William Peskett for checking the written English and our colleagues from the Department of Plant Developmental Biology for critical reading and comments on the manuscript.

Conflicts of Interest: The authors declare no conflict of interest.

\section{References}

1. Lack, H.W. The discovery and rediscovery of the horse chestnut. Arnoldia 2002, 61, 15-19. [CrossRef]

2. Deschka, G.; Dimić, N. Cameraria ohridella sp. n. (Lep., Lithocolletidae) from Macedonia, Yugoslavia. Acta Entomol. Jugosl. 1986, $22,11-23$.

3. Šefrova, H.; Laštůvka, Z. Dispersal of the horse chestnut leaf miner, Cameraria ohridella Descha \& Dimić, 1986, in Europe: Its course, ways and causes (lepidoptera: Gracillariidae). Entomol. Z. Stuttg. 2001, 111, 194-198.

4. Straw, N.A.; Bellett-Travers, M. Impact and Management of the Horse Chestnut Leaf Miner (Cameraria ohridella). Arboric. J. 2004, 28, 67-83. [CrossRef]

5. Thalmann, C.; Freise, J.; Heitland, W.; Bacher, S. Effects of Defoliation by Horse Chestnut Leafminer (Cameraria ohridella) on Reproduction in Aesculus hippocastanum. Trees-Struct. Funct. 2003, 17, 383-388. [CrossRef]

6. Myśkow, E.; Sokołowska, K.; Słupianek, A.; Gil, R. Drukarnia Triada Co gryzie kasztanowiec? Wptyw Szrotówka Kasztanowcowiaczka na Fenologie i Rozwój Drzew. What's Eating Horse Chestnut? The Influence of Horse-Chestnut Leaf Miner on Tree Phenology and Development; Wydawnictwo i Drukarnia Triada: Wrocław, Poland, 2017; ISBN 978-83-61777-72-4.

7. Raimondo, F.; Ghirardelli, L.A.; Nardini, A.; Salleo, S. Impact of the Leaf Miner Cameraria ohridella on Photosynthesis, Water Relations and Hydraulics of Aesculus hippocastanum Leaves. Trees 2003, 17, 376-382. [CrossRef]

8. Percival, G.C.; Barrow, I.; Nosviss, K.; Keary, I.; Pennington, P. The Impact of Horse Chestnut Leaf Miner (Cameraria ohridella Deschka and Dimic; HCLM) on Vitality, Growth and Reproduction of Aesculus hippocastanum L. Urban For. Urban Green. 2011, 10, 11-17. [CrossRef]

9. Takos, I.; Varsamis, G.; Avtzis, D.; Galatsidas, S.; Merou, T.; Avtzis, N. The Effect of Defoliation by Cameraria ohridella Deschka and Dimic (Lepidoptera: Gracillariidae) on Seed Germination and Seedling Vitality in Aesculus hippocastanum L. For. Ecol. Manag. 2008, 255, 830-835. [CrossRef]

10. Larson, P.R. The Vascular Cambium; Springer Series in Wood Science; Springer: Berlin/Heidelberg, Germany, 1994; ISBN 978-3-64278468-2.

11. Evert, R.F.; Esau, K.; Esau, K. Esau's Plant Anatomy: Meristems, Cells, and Tissues of the Plant Body: Their Structure, Function, and Development, 3rd ed.; Wiley-Interscience: Hoboken, NJ, USA, 2006; ISBN 978-0-471-73843-5.

12. García-Gonzalez, I.; Eckstein, D. Climatic Signal of Earlywood Vessels of Oak on a Maritime Site. Tree Physiol. 2003, 23, 497-504. [CrossRef]

13. Marion, L.; Gričar, J.; Oven, P. Wood Formation in Urban Norway Maple Trees Studied by the Micro-Coring Method. Dendrochronologia 2007, 25, 97-102. [CrossRef]

14. Eilmann, B.; Buchmann, N.; Siegwolf, R.; Saurer, M.; Cherubini, P.; Rigling, A. Fast Response of Scots Pine to Improved Water Availability Reflected in Tree-Ring Width and $\Delta 13$ C. Plant Cell Environ. 2010, 33, 1351-1360. [CrossRef] [PubMed]

15. Ursache, R.; Nieminen, K.; Helariutta, Y. Genetic and Hormonal Regulation of Cambial Development. Physiol Plant. 2013, 147, 36-45. [CrossRef]

16. Eckert, C.; Sharmin, S.; Kogel, A.; Yu, D.; Kins, L.; Strijkstra, G.-J.; Polle, A. What Makes the Wood? Exploring the Molecular Mechanisms of Xylem Acclimation in Hardwoods to an Ever-Changing Environment. Forests 2019, 10, 358. [CrossRef]

17. Čufar, K.; Prislan, P.; de Luis, M.; Gričar, J. Tree-Ring Variation, Wood Formation and Phenology of Beech (Fagus sylvatica) from a Representative Site in Slovenia, SE Central Europe. Trees 2008, 22, 749-758. [CrossRef]

18. Michelot, A.; Simard, S.; Rathgeber, C.; Dufrene, E.; Damesin, C. Comparing the Intra-Annual Wood Formation of Three European Species (Fagus sylvatica, Quercus petraea and Pinus sylvestris) as Related to Leaf Phenology and Non-Structural Carbohydrate Dynamics. Tree Physiol. 2012, 32, 1033-1045. [CrossRef] [PubMed]

19. Kitin, P.; Funada, R. Earlywood Vessels in Ring-Porous Trees Become Functional for Water Transport after Bud Burst and before the Maturation of the Current-Year Leaves. IAWA J. 2016, 37, 315-331. [CrossRef] 
20. Lavrič, M.; Eler, K.; Ferlan, M.; Vodnik, D.; Gričar, J. Chronological Sequence of Leaf Phenology, Xylem and Phloem Formation and Sap Flow of Quercus pubescens from Abandoned Karst Grasslands. Front. Plant Sci. 2017, 8. [CrossRef] [PubMed]

21. Gričar, J.; Krže, L.; Čufar, K. Number of Cells in Xylem, Phloem and Dormant Cambium in Silver Fir (Abies alba), in Trees of Different Vitality. IAWA J. 2009, 30, 121-133. [CrossRef]

22. Gričar, J.; Čufar, K.; Eler, K.; Gryc, V.; Vavrčík, H.; de Luis, M.; Prislan, P. Transition Dates from Earlywood to Latewood and Early Phloem to Late Phloem in Norway Spruce. Forests 2021, 12, 331. [CrossRef]

23. Gričar, J. Xylem and Phloem Formation in Sessile Oak from Slovenia in 2007. Wood Res. 2010, 55, $15-22$.

24. Prislan, P.; Gričar, J.; de Luis, M.; Smith, K.T.; Čufar, K. Phenological Variation in Xylem and Phloem Formation in Fagus sylvatica from Two Contrasting Sites. Agric. For. Meteorol. 2013, 180, 142-151. [CrossRef]

25. Balzano, A.; Čufar, K.; de Micco, V. Xylem and Phloem Formation Dynamics in Quercus ilex L. at a Dry Site in Southern Italy. Forests 2021, 12, 188. [CrossRef]

26. Chiang, M.-H.; Greb, T. How to Organize Bidirectional Tissue Production? Curr. Opin. Plant Biol. 2019, 51, 15-21. [CrossRef] [PubMed]

27. Wodzicki, T.J. Natural Factors Affecting Wood Structure. Wood Sci. Technol. 2001, 35, 5-26. [CrossRef]

28. Bräuning, A.; De Ridder, M.; Zafirov, N.; García-González, I.; Petrov Dimitrov, D.; Gärtner, H. Tree-Ring Features: Indicators of Extreme Event Impacts. IAWA J. 2016, 37, 206-231. [CrossRef]

29. Begum, S.; Kudo, K.; Rahman, M.H.; Nakaba, S.; Yamagishi, Y.; Nabeshima, E.; Nugroho, W.D.; Oribe, Y.; Kitin, P.; Jin, H.-O.; et al. Climate Change and the Regulation of Wood Formation in Trees by Temperature. Trees 2018, 32, 3-15. [CrossRef]

30. Castagneri, D.; Fonti, P.; von Arx, G.; Carrer, M. How Does Climate Influence Xylem Morphogenesis over the Growing Season? Insights from Long-Term Intra-Ring Anatomy in Picea Abies. Ann. Bot. 2017, mcw274. [CrossRef] [PubMed]

31. Myśkow, E.; Błaś, M.; Sobik, M.; Godek, M.; Owczarek, P. The Effect of Pollutant Fog Deposition on the Wood Anatomy of Subalpine Norway Spruce. Eur. J. For. Res. 2019, 138, 187-201. [CrossRef]

32. Büntgen, U.; Frank, D.; Liebhold, A.; Johnson, D.; Carrer, M.; Urbinati, C.; Grabner, M.; Nicolussi, K.; Levanic, T.; Esper, J. Three Centuries of Insect Outbreaks across the European Alps. New Phytol. 2009, 182, 929-941. [CrossRef]

33. Axelson, J.N.; Bast, A.; Alfaro, R.; Smith, D.J.; Gärtner, H. Variation in Wood Anatomical Structure of Douglas-Fir Defoliated by the Western Spruce Budworm: A Case Study in the Coastal-Transitional Zone of British Columbia, Canada. Trees 2014, 28, 1837-1846. [CrossRef]

34. Prendin, A.L.; Carrer, M.; Karami, M.; Hollesen, J.; Bjerregaard Pedersen, N.; Pividori, M.; Treier, U.A.; Westergaard-Nielsen, A.; Elberling, B.; Normand, S. Immediate and Carry-over Effects of Insect Outbreaks on Vegetation Growth in West Greenland Assessed from Cells to Satellite. J. Biogeogr 2020, 47, 87-100. [CrossRef]

35. Bednarz, B.; Scheffler, M. Wpływ żeru szrotówka kasztanowcowiaczka (Cameraria ohridella Deschka \& Dimic) na szerokość przyrostów rocznych kasztanowca białego (Aesculus hippocastanum L.). Effect of horse chestnut leaf miner (Cameraria ohridella Deschka and Dimic) outbreak on tree-ring widths of white horse chestnut (Aesculus hippocastanum L.). Sylwan 2008, 7, 53-66.

36. Jagiełło, R.; Baraniak, E.; Karolewski, P.; Łakomy, P.; Behnke-Borowczyk, J.; Walczak, U.; Giertych, M.J. Ecophysiological Aspects of the Interaction between Cameraria ohridella and Guignardia aesculi on Aesculus hippocastanum. Dendrobiology 2017, 78, 146-156. [CrossRef]

37. Jagiełło, R.; Walczak, U.; Iszkuło, G.; Karolewski, P.; Baraniak, E.; Giertych, M.J. Impact of Cameraria ohridella on Aesculus hippocastanum Growth and Long-Term Effects of Trunk Injection with Pesticides. Int. J. Pest. Manag. 2019, 65, 33-43. [CrossRef]

38. IMGW (Institute of Meteorology and Water Management); National Research Institute. Available online: https://www.imgw.pl/ index.php/en (accessed on 28 May 2021).

39. Gilbert, M.; Svatoš, A.; Lehmann, M.; Bacher, S. Spatial Patterns and Infestation Processes in the Horse Chestnut Leafminer Cameraria ohridella: A Tale of Two Cities. Entomol. Exp. Appl. 2003, 107, 25-37. [CrossRef]

40. Nardini, A.; Raimondo, F.; Scimone, M.; Salleo, S. Impact of the Leaf Miner Cameraria ohridella on Whole-Plant Photosynthetic Productivity of Aesculus hippocastanum: Insights from a Model. Trees 2004, 18, 714-721. [CrossRef]

41. Pavan, F.; Barro, P.; Bernardinelli, I.; Gambon, N.; Zandigiacomo, P. Cultural Control of Cameraria ohridella on Horse Chesnut in Urban Areas by Removing Fallen Leaves in Autumn. J. Arboric. 2003, 29, 253-258.

42. Gričar, J.; Lavrič, M.; Ferlan, M.; Vodnik, D.; Eler, K. Intra-Annual Leaf Phenology, Radial Growth and Structure of Xylem and Phloem in Different Tree Parts of Quercus pubescens. Eur. J. For. Res. 2017, 136, 625-637. [CrossRef]

43. Rossi, S.; Anfodillo, T.; Menardi, R. Trephor: A New Tool for Sampling Microcores from Tree Stems. IAWA J. 2006, 27, 89-97. [CrossRef]

44. Giagli, K.; Gričar, J.; Vavrčík, H.; Menšík, L.; Gryc, V. The Effects of Drought on Wood Formation in Fagus sylvatica during Two Contrasting Years. IAWA J. 2016, 37, 332-348. [CrossRef]

45. Ruzin, S.E. Plant. Microtechnique and Microscopy; Oxford University Press: New York, NY, USA, 1999; ISBN 978-0-19-508956-1.

46. Oladi, R.; Pourtahmasi, K.; Eckstein, D.; Bräuning, A. Seasonal Dynamics of Wood Formation in Oriental Beech (Fagus orientalis Lipsky) along an Altitudinal Gradient in the Hyrcanian Forest, Iran. Trees 2011, 25, 425-433. [CrossRef]

47. Barnett, J.R. Reactivation of the Cambium in Aesculus hippocastanum L.: A Transmission Electron Microscope Study. Ann. Bot. 1992, 70, 169-177. [CrossRef]

48. Ewers, F.W.; Fisher, J.B. Techniques for Measuring Vessel Lengths and Diameters in Stems of Woody Plants. Am. J. Bot. 1989, 76, 645-656. [CrossRef] 
49. Giordano, R.; Salleo, A.; Salleo, S.; Wanderlingh, F. Flow in Xylem Vessels and Poiseuille's Law. Can. J. Bot. 1978, 56, 333-338. [CrossRef]

50. Venturas, M.; López, R.; Gascó, A.; Gil, L. Hydraulic Properties of European Elms: Xylem Safety-Efficiency Tradeoff and Species Distribution in the Iberian Peninsula. Trees 2013, 27, 1691-1701. [CrossRef]

51. Zar, J.H. Biostatistical Analysis, 4th ed.; Prentice-Hall: Upper Saddle River, NJ, USA, 1998.

52. Frankenstein, C.; Eckstein, D.; Schmitt, U. The Onset of Cambium Activity-A Matter of Agreement? Dendrochronologia 2005, 23, 57-62. [CrossRef]

53. Sundberg, B.; Uggla, C.; Tuominen, H. Cambial growth and auxin gradients. In Cell and Molecular Biology of Wood Formation; Savidge, R.A., Barnett, J.R., Napier, R., Eds.; Experimental biology reviews; BIOS: Oxford, UK, 2000; pp. 169-188. ISBN 978-1-85996-123-0.s.

54. Fonti, P.; von Arx, G.; García-González, I.; Eilmann, B.; Sass-Klaassen, U.; Gärtner, H.; Eckstein, D. Studying Global Change through Investigation of the Plastic Responses of Xylem Anatomy in Tree Rings. New Phytol. 2010, 185, 42-53. [CrossRef]

55. Aloni, R. Ecophysiological Implications of Vascular Differentiation and Plant Evolution. Trees 2015, 29, 1-16. [CrossRef]

56. Schrader, J.; Baba, K.; May, S.T.; Palme, K.; Bennett, M.; Bhalerao, R.P.; Sandberg, G. Polar Auxin Transport in the Wood-Forming Tissues of Hybrid Aspen Is under Simultaneous Control of Developmental and Environmental Signals. Proc. Natl. Acad. Sci. USA 2003, 100, 10096-10101. [CrossRef]

57. Asshoff, R.; Schweingruber, F.H.; Wermelinger, B. Influence of a Gypsy Moth (Lymantria dispar L.) Outbreak on Radial Growth and Wood Anatomy of Spanish Chestnut (Castanea sativa Mill.) in Ticino (Switzerland). Dendrochronologia 1999, 16-17, 133-145.

58. Dobbertin, M. Tree Growth as Indicator of Tree Vitality and of Tree Reaction to Environmental Stress: A Review. Eur. J. For. Res. 2005, 124, 319-333. [CrossRef]

59. De Micco, V.; Zalloni, E.; Balzano, A.; Battipaglia, G. Fire Influence on Pinus halepensis: Wood Responses Close and Far from the Scars. IAWA J. 2013, 34, 446-458. [CrossRef]

60. Fajstavr, M.; Giagli, K.; Vavrčík, H.; Gryc, V.; Urban, J. The Effect of Stem Girdling on Xylem and Phloem Formation in Scots Pine. Silva. Fenn. 2017, 51. [CrossRef]

61. Salleo, S.; Nardini, A.; Raimondo, F.; Lo Gullo, M.A.; Pace, F.; Giacomich, P. Effects of Defoliation Caused by the Leaf Miner Cameraria ohridella on Wood Production and Efficiency in Aesculus hippocastanum Growing in North-Eastern Italy. Trees 2003, 17, 367-375. [CrossRef]

62. Słupianek, A.; Wojtuń, B.; Myśkow, E. Origin, Activity and Environmental Acclimation of Stem Secondary Tissues of the Polar Willow (Salix polaris) in High-Arctic Spitsbergen. Polar Biol. 2019, 42, 759-770. [CrossRef]

63. Rodriguez-Zaccaro, F.D.; Groover, A. Wood and Water: How Trees Modify Wood Development to Cope with Drought. Plants People Planet 2019, 1, 346-355. [CrossRef]

64. Crawley, M.J. Insect Herbivores and Plant Population Dynamics. Annu. Rev. Entomol. 1989, 34, 531-564. [CrossRef]

65. Kosola, K.R.; Dickmann, D.I.; Paul, E.A.; Parry, D. Repeated Insect Defoliation Effects on Growth, Nitrogen Acquisition, Carbohydrates, and Root Demography of Poplars. Oecologia 2001, 129, 65-74. [CrossRef] [PubMed]

66. Wiley, E.; Huepenbecker, S.; Casper, B.B.; Helliker, B.R. The Effects of Defoliation on Carbon Allocation: Can Carbon Limitation Reduce Growth in Favour of Storage? Tree Physiol. 2013, 33, 1216-1228. [CrossRef]

67. Jetton, R.M.; Robison, D.J. Effects of Artificial Defoliation on Growth and Biomass Accumulation in Short-Rotation Sweetgum (Liquidambar styraciflua) in North Carolina. J. Insect Sci. 2014, 14, 1-14. [CrossRef]

68. Rosas, T.; Galiano, L.; Ogaya, R.; Penuelas, J.; Martinez-Vilalta, J. Dynamics of Non-structural Carbohydrates in Three Mediterranean Woody Species Following Long-term Experimental Drought. Front. Plant Sci. 2013, 4, 400. [CrossRef] [PubMed]

69. Yoshimura, K.; Saiki, S.-T.; Yazaki, K.; Ogasa, M.Y.; Shirai, M.; Nakano, T.; Yoshimura, J.; Ishida, A. The Dynamics of Carbon Stored in Xylem Sapwood to Drought-induced Hydraulic Stress in Mature Trees. Sci. Rep. 2016, 4, 24513. [CrossRef] [PubMed]

70. Pace, M.R. Phloem: Cell Types, Structure, and Commercial Uses. In Plant Science-Structure, Anatomy and Physiology in Plants Cultured In Vivo and In Vitro; Gonzalez, A., Rodriguez, M., Gören Sağlam, N., Eds.; IntechOpen: London, UK, 2020; ISBN 978-1-78984-746-8. 